\title{
GTF3C3 wt Allele
}

National Cancer Institute

\section{Source}

National Cancer Institute. GTF3C3 wt Allele. NCI Thesaurus. Code C52630.

Human GTF3C3 wild-type allele is located in the vicinity of 2 q33.1 and is approximately 36 $\mathrm{kb}$ in length. This allele, which encodes general transcription factor $3 \mathrm{C}$ polypeptide 3 protein, is involved in the modulation of both transfer RNA and ribosome production. 